\title{
Analgesic Activity of Dichloromethanolic Root Extract of Clutia abyssinica in Swiss Albino Mice
}

\author{
Koech SC*, Ouko RO, Michael NM, Ireri MM, Ngugi MP and Njagi NM
}

Department of Biochemistry and Biotechnology, School of Pure and Applied Sciences, Kenyatta University, PO Box 43844-00100, Nairobi, Kenya

\begin{abstract}
Pain as a sensory modality, represent a symptom for diagnosing various diseases and its associated conditions. Although it acts as a sensory modality in drawing attention to tissue injury, it is associated with poor quality of life and socioeconomic burden to the victim. Conventional synthetic drugs that are used to manage pain are not readily available and are associated with adverse effects. Thus, the use of herbal medicine from medicinal plants is an age old practice used by many communities to cure diseases. These medicinal plants are known to contain phytochemical compounds capable of relieving pain and healing diseases. C. abyssinica has been used traditionally by the Kallenjin community to alleviate various diseases. However, an extensive search of the literature reveals that no data has been documented about the medicinal use of the plant in suppressing pain. The present study thus, evaluated on analgesic potential of dichloromethanolic root extract of $C$. abyssinica in animal models. Thirty Swiss albino mice were grouped into six groups of five animal each; normal control, negative control, positive control and three experimental groups. The experimental animals were administered with the extract intraperitoneally at dose level of 50,100 and $150 \mathrm{mg} /$ $\mathrm{kg}$ body weight. Acetic acid-induced pain was used to determine the analgesic activity of the extract. Diclofenac was used as a reference drug. The dichloromethanolic root extract reduced the number of abdominal writhing's between $33.95 \%$ and $49.77 \%$ while the reference drug reduced the number of abdominal writhing's by $46.51 \%$. A number of phytochemical compounds associated with analgesic activity were observed to be present. The study therefore scientifically confirmed the traditional use of the medicinal plant in management of pain.
\end{abstract}

\section{Keywords: Pain; C. abyssinica; Herbal; Mice}

\section{Introduction}

The International association for the study of pain defines pain as "unpleasant sensory and emotional experience that is caused by actual or potential tissue damage". The emotional component differs from one person to the other and in the same individual from time to time and it can be classified in several ways, but in therapeutic application into; nociceptive and neuropathic [1]. In the body, Sensory nerve endings are generally found in every part of the body such as the blood vessels, internal organs, muscles, joints, and the skin [2]. Damage caused by the chemical stimuli, mechanical stimuli, and thermal stimuli sensitize nociceptors. When cells are damaged a number of chemical mediators are released which then activate and sensitize nociceptors to other mediators of pain. Major mediators of pain include; Bradykinin, histamine, serotonin and prostaglandins [3]. However, pain is beyond sensation, it comprises of perception and subjective interpretation of the discomfort [4]. Sensation of pain is a sign that something in the body is wrong. Thus it plays an important role in drawing attention to tissue injury from harmful stimuli and reflexes are elicited to protect the injured part of the body [5].

In the brain, pain stimulus is processed and generated impulses are send down the spinal cord following the appropriate nerves and instructs the body to respond, for instance withdrawing your hand from the fire [5]. Peripheral nerves transmit pain stimulus to the spinal cord which then links to the brain. Two types of nerve fibers are involved in this process; slow pain fibers and Fast pain fibers. Transmission of fast pain is through the A $\delta$ fibers to the spinal cord while slow pain fibers is through the C-fibers. Fast pain nerve endings secrete neurotransmitter called glutamate, which transmits fast pain impulses to the brain in the cortex. Therefore localization of pain in certain part of the body becomes relatively precise [5].

Although pain is beneficial to the immune system. However, it causes a lot of suffering and discomfort to the victims, lowering the quality of life and therefore need to be managed. To suppress pain, NSAIDs are prescribed all over the world [6,7]. For severe or chronic malignant pain opioids analgesics are drugs of choice [8]. However, prolonged use of these NSAIDs only provides asymptomatic relief and the greatest drawback lies in their toxicity to liver, kidney and gastrointestinal linings [9]. In this regard, herbal medicines from medicinal plants have been employed in complementary and alternative medicine (CAM) for treatment of pain as well as diseases related to these conditions [10]. Traditional medicinal herbs for over centuries have served as potential source for alternative medicine and the knowledge of herbal medicine has been passed on from generation to generation [11]. Considering that most of analgesic, anti-malarial and anti-pyretic synthetic drugs such as aspirin, morphine, artemisinin, atrophine and chloroquine were derived from the plant products [12].

The use herbal medicine is gaining support and recognition across the world because most of these products are believed to have bioactive compounds responsible for healing various diseases without any side effects and at a lower cost. C. abyssinica is native to East Africa, Central Africa and South Africa [13]. In East Africa roots and leafs of the plant are boiled and the soup taken as a remedy for chest pains, enlarged spleen and shortness of breath [13]. Although, it has been used traditionally by the Kallenjin community in Kenya to treat pain and its associated conditions. However, the aforementioned folklore use of the plant lacks scientific validated data. Therefore, the aim of the study was to evaluate analgesic potential of dichloromethanolic roots extract of $C$. abyssinica in Swiss albino mice.

*Corresponding author: Koech Samson Cheruiyot, Department of Biochemistry and Biotechnology, Kenyatta University, PO Box 43844-00100, Nairobi, Kenya, Tel: +254728002111; E-mail: koechsam22@gmail.com

Received February 08, 2017; Accepted February 16, 2017; Published February 23, 2017

Citation: Koech SC, Ouko RO, Michael NM, Ireri MM, Ngugi MP, et al. (2017) Analgesic Activity of Dichloromethanolic Root Extract of Clutia abyssinica in Swiss Albino Mice. Nat Prod Chem Res 5: 255. doi: 10.4172/2329-6836.1000255

Copyright: $\odot 2017$ Koech SC, et al. This is an open-access article distributed under the terms of the Creative Commons Attribution License, which permits unrestricted use, distribution, and reproduction in any medium, provided the original author and source are credited. 


\section{Materials and Methodology}

\section{Plant sample collection and preparation}

The roots sample were collected from Kaptebee village, turbo subcounty in Uasin Gishu county Kenya during the months of Januarymarch, a period in which the herbalist believed the medicinal plant had its utmost healing capacity to cure the named ailments. This process of collection of the plant sample was done with the guidance of a local herbalist. A voucher specimen consisting of fresh twigs with leaves was availed to an acknowledged taxonomist for botanical authentication. A sample voucher (NMK/BOT/CTX1/2) was deposited at the National Museum of Kenya herbarium. Sample roots were then sorted, cut into smaller pieces and cleaned with clean water and then air dried under shade for two weeks. Chopped root samples were packed into paper enveloped and transported to Kenyatta University laboratory where they were milled into fine powder using an electrical mill.

\section{Extraction}

For extraction, 1.3 liters of dichloromethane was used to soak 400 $\mathrm{g}$ of the powdered root sample for 48 hours with occasional shaking within the first 10 hours to mix the sample uniformly on hourly basis. Whatman's filter paper No.1 was used to filter the mixture. The filtrate was concentrated to dryness using the rotary evaporator at a temperature of $41^{\circ} \mathrm{C}$. The concentrates was kept in sealed containers at low temperature until use in bio screening experiments.

\section{Experimental Design}

\section{Laboratory animals}

Thirty Swiss albino mice weighing between 19-24 g were utilized for screening analgesic potential of DCM root extract of C. abyssinica. Standard laboratory cages were used to handle the experimental animals in the animal house at Kenyatta University. During the entire period of carrying out the research all the laboratory animals were kept in ambient room temperature for 12 hours darkness followed by 12 hours light cycles. Rodent pellets were used to feed the experimental animals and allowed access to water ad libitum. Rules and regulation for handling experimental animals in the study were adhered to [14].

\section{Determination of analgesic effect}

Analgesic activity of DCM root extract of C. abyssinica was determined through acetic acid-induced pain in experimental animals following the procedure described by [15] and [16]. A total of thirty Swiss albino mice were grouped into 6 groups of five animals each. Prior to pain induction and administration of the experimental doses, all the experimental animals were fasted for 12 hours but were allowed access to water ad libitium. Pain was induced by injecting 3\% acetic acid solution at a dose of $20 \mathrm{~mL} / \mathrm{kg}$ body weight into the left side of the abdomen intraperitoneally. Immediately, after injection with aceticacid abdominal muscle constriction in the abdomen and turning of body trunk of the laboratory animal was seen as an indication of pain. The different groups were treated as follows; Group I (normal control) was administered with $10 \%$ DMSO only but pain was not induced. All the animals in group II (negative control) were induced with pain and administered with $10 \%$ DMSO. Those in group III (positive control) were induced with pain and administered with the reference drug (diclofenac $15 \mathrm{mg} / \mathrm{kg}$ body weight). Group IV-VI were induced with pain and administered with DCM root extract of C. abyssinica at dose levels of 50,100 and $150 \mathrm{mg} / \mathrm{kg}$ body weight respectively. Table 1 indicates the summary of the design.
Thirty minutes after different treatments were administered, each mouse in groups II-VI was intraperitoneally (ip) injected with $3 \%$ acetic acid into the left side of the abdomen at a dose of $20 \mathrm{ml} / \mathrm{kg}$ body weight to induce pain sensation except those in group I, which were administered with the vehicle (10\% DMSO) only. Each mouse was then placed in a transparent observation box and the number of abdominal constrictions (writhes) for each mouse was counted for 30 minutes commencing 5 minutes after intraperitoneal injection of acetic acid. The percentage writhing inhibition was then calculated using the formula described by [17].

$$
\% \text { Writhing inhibition }=\frac{C-T}{C} \times 100
$$
value.

Where, C- The vehicle-treated control group; T - Treated group

\section{Qualitative phytochemical screening}

The plant extract was subjected to qualitative phytochemical screening to determine the presence or absence of various phytochemical compounds following a protocol described by [18] Flavonoids, phenolics, saponins, alkaloids cardiac glycosides, steroids and terpenoids were some of the phytochemical compounds tested. These secondary metabolites have been associated with analgesic activities (Table 2).

\section{Data management and statistical analysis}

Raw data on the number of abdominal writhing was obtained from the experimental animals, recorded and tabulated on a broad sheet using Ms excel program. Data was then exported to Minitab version 17.0 for analysis. Data was subjected to descriptive statistics and results were expressed as Mean \pm Standard Error of the Mean (SEM). One way ANOVA was used to analyse for statistical significance among the groups followed by Tukey's test for separation of means and comparison of significant difference among the various groups. Data was presented in a Table 3 . A value of $\mathrm{P} \leq 0.05$ was considered significant.

\section{Results}

\begin{tabular}{|c|c|}
\hline Group & Treatment \\
\hline I (Normal control) & $10 \%$ DMSO only \\
\hline II (Negative control) & $3 \%$ Acetic acid \\
\hline III (Positive control) & $3 \%$ Acetic acid+diclofenac $(15 \mathrm{mg} / \mathrm{kg} \mathrm{bw})$ \\
\hline IV (Experimental group A) & $3 \%$ cetic acid + C. abyssinica $(50 \mathrm{mg} / \mathrm{kg} \mathrm{bw})$ \\
\hline V (Experimental group B) & $3 \%$ Acetic acid + C. abyssinica $(100 \mathrm{mg} / \mathrm{kg} \mathrm{bw})$ \\
\hline VI (Experimental group C) & $3 \%$ Acetic acid + C. abyssinica $(150 \mathrm{mg} / \mathrm{kg} \mathrm{bw})$ \\
\hline
\end{tabular}

Table 1: Treatment protocol for assessment of analgesic activity of DCM root extract of $C$. abyssinica in Swiss albino mice

\begin{tabular}{|c|c|}
\hline Phytochemicals & DCM root extract of C.abyssinica \\
\hline Alkaloids & + \\
\hline Flavonoids & + \\
\hline Steroids & + \\
\hline Saponins & + \\
\hline Cardiac glycosides & - \\
\hline Phenolics & + \\
\hline Terpenoids & + \\
\hline
\end{tabular}

Present phytochemicals denoted by (+), absent phytochemicals denoted by (-).

Table 2: Qualitative pphytochemical composition of DCM root extract of $C$. abyssinica 


\begin{tabular}{|c|c|c|}
\hline Group & Treatment & $\%$ inhibition \\
\hline Normal Control & $10 \%$ DMSO & $100.00 \pm 0.0^{\mathrm{a}}$ \\
\hline Negative Control & Acetic acid+DMSO & $0.00 \pm 0.0^{\mathrm{c}}$ \\
\hline Positive Control & $\begin{array}{c}\text { Acetic acid+Diclofenac }(15 \mathrm{mg} / \\
\mathrm{kg} \text { bw) }\end{array}$ & $46.51 \pm 4.22^{\mathrm{b}}$ \\
\hline Experimental group A & $\begin{array}{c}\text { Acetic acid+C. abyssinica }(50 \mathrm{mg} / \\
\mathrm{kg} \text { bw) }\end{array}$ & $49.77 \pm 4.69^{\mathrm{b}}$ \\
\hline Experimental group B & $\begin{array}{c}\text { Acetic acid+C. abyssinica }(100 \\
\mathrm{mg} / \mathrm{kg} \text { bw) }\end{array}$ & $38.60 \pm 4.33^{\mathrm{b}}$ \\
\hline Experimental group C & $\begin{array}{r}\text { Acetic acid+C. abyssinica }(150 \\
\mathrm{mg} / \mathrm{kg} \text { bw) }\end{array}$ & $33.95 \pm 8.01^{\mathrm{b}}$ \\
\hline
\end{tabular}

Table 3: Analgesic activities of DCM root extracts of $C$. abyssinica on acetic acidInduced pain in Swiss albino mice.

\section{Analgesic activity of DCM root extracts of $C$. abyssinica on acetic acid-induced pain in swiss albino mice}

The DCM root extract of C. abyssinica demonstrated an analgesic activity in acetic acid-induced pain in Swiss albino male mice by reducing the number of abdominal writhes 30 minutes after the administration of the plant extract (Table 3). The intraperitoneal administration of DCM root extracts of C. abyssinica into Swiss albino mice at all the three dose levels (50,100 and $150 \mathrm{mg} / \mathrm{kg}$ body weights), reduced the number of abdominal writhing by $49.3 \%, 38.6 \%$ and $33.95 \%$ respectively (Table 3 ). However, diclofenac (reference drug) reduced the number of abdominal writhes by $46.51 \%$ (Table 3 ). At a dose level of $50 \mathrm{mg} / \mathrm{kg}$ body weight, the extract demonstrated strong analgesic activity by reducing the number of abdominal writhes by $49.3 \%$ compared to the diclofenac (reference drug) which caused $46.1 \%$ reduction of abdominal writhes.

The analgesic effects of DCM root extract of C. abyssinica showed no significant difference at the three doses and were comparable to diclofenac ( $\mathrm{P}>0.05$; Table 3$)$. The DCM root extract of C. abyssinica, at the three dose levels (50, 100 and $150 \mathrm{mg} / \mathrm{kg}$ body weight), reduced the number of abdominal writhing's in a reverse dose dependent manner (Table 3).

\section{Discussion}

The present study was designed to evaluate the analgesic potential of DCM root extract of C. abyssinica in Swiss albino mice. To evaluate the analgesic activity of the DCM root extract, acetic acid-induced pain test was used to induce abdominal writhing's in Swiss albino mice. Acetic acid-induced pain test has widely been used for screening new analgesic agents and it majorly involves cholinergic, histaminic peritoneal receptors, acetylcholine and histamine mediators. It is also used to asses peripherally acting analgesics [19,20]. According to [21] several chemicals can be used to induce writhing's in a laboratory animal for example acetic acid and phenylquinone. When acetic acid is intraperitoneally injected into the experimental animal the following characteristics are observed as indicators of pain; contraction of abdominal muscle, elongation of body part and extension of the hind limbs. Therefore, such presentation is thought to be mediated by peritoneal receptors [22]. It has been proposed that acetic acid acts indirectly by releasing endogenous substances responsible for exciting the nerve endings and causing pain, but also excites neurons that are sensitive to drugs [20].

To suppress pain conventionally, nonsteroidal anti-inflammatory drugs are prescribed [23]. These drugs are used for treating various diseases such as arthritis, headache, pain and orthopedic conditions [6]. Analgesic drugs such as diclofenac relieve pain peripherally/centrally by inhibiting cyclooxygenase enzyme (COX-1 and COX-2). Inhibition of cyclooxygenase enzyme reduces the production of pain mediators such as prostaglandins, substance $\mathrm{P}$, histamine, serotonin, and Bradykinin. Pain sensation is eventually reduced in the nociceptors [24].

The DCM root extract of C. abyssinica in this study, exhibited analgesic activities by reducing the number of abdominal writhes in acetic acid-induced pain in male Swiss albino mice after treatment with the extract. After thirty minutes of test period, the DCM root extract at $50 \mathrm{mg} / \mathrm{kg}$ body weight demonstrated the highest analgesic activity by reducing the number of writhes by $49.77 \%$, while $100 \mathrm{mg} / \mathrm{kg}$ body weight decreased the number of writhes by $38.6 \%$ and the dose of 150 $\mathrm{mg} / \mathrm{kg}$ body weight decreased the number of writhes by $33.95 \%$ in a reverse dose dependent manner (Table 2).

These findings strongly suggest that the DCM root extract of $C$. abyssinica possess peripherally or centrally analgesic property. Perhaps acting in a similar manner as conventionally used therapeutic drugs that reduce the pain perception in nociceptors by inhibiting production of prostaglandins. These results concur with other research studies on the evaluation analgesic activity of herbal plants extract using laboratory animals. Reduction in the number of abdominal writhing's in this study is in agreement with a study carried out by [25] on analgesic properties of acetone leaf extracts of Carissa spinarum in mice. The findings are also in line with studies by [26] on antinociceptive activity of Toddalia asiatica (L) Lam in models of central and peripheral pain.

The non-dose dependent analgesic activities of DCM root extract of C. abyssinica, are in agreement with a study carried out by [27] on analgesic activities of root and leaf extract of Carissa edulis in Wistar albino rats. The higher analgesic activity of a dose level of $50 \mathrm{mg} / \mathrm{kg}$ body weight than $150 \mathrm{mg} / \mathrm{kg}$ body weight (Table 3 ) might be attributed to the fact that when certain limits in dose ranges are exceeded, the activity of that particular agent is reduced. Also, high dose concentration of the extract could be taking longer time to be absorbed across peritoneum cavity. Analgesic effects produced by a lower dose was comparable to the reference drug, suggesting that the lower dose was more effective in managing pain induced by acetic acid. The dose range of $(50,100$ and $150 \mathrm{mg} / \mathrm{kg}$ body weight) applied in bio screening of analgesic activities of DCM root extract in the study were comparable to dose ranges used by while evaluating the antipyretic, anti-inflammatory and analgesic activity of Acacia hydaspica R. Parker in animal models.

The analgesic activities of DCM root extract of C. abyssinica could be attributed to one or more of phytochemical compounds present in the extract (Table 2). Studies conducted on herbal plants by many researchers have linked presence of secondary active metabolites such as flavonoids, saponins and alkaloids to analgesic activities among other properties $[28,29]$. Flavonoids have the ability to disrupt synthesis of eicosanoids [30]. Flavonoids also have the ability to reduce production of arachidonic acid through inhibition of neutrophils degranulation [31]. Besides flavonoids, alkaloids also have been associated with the ability to inhibit pain perception [32]. Alkaloids, for example berberine from berberies in a skeletal based pyridine ring have shown strong anti-inflammatory and antinociceptive activities [33]. These mentioned phytochemicals were confirmed in preliminary phytochemical screening of DCM root extract of C. abyssinica (Table 2). Therefore, the phytochemicals found in the extract might have antagonized peripheral mediators of pain and thereby blocking transmission of pain. 


\section{Conclusion}

The dichloromethanolic root extract of C. abyssinica demonstrated analgesic activities on acetic acid-induced pain in Swiss albino mice. The extract reduced the number of abdominal writhing's significantly when compared to the reference drug (diclofenac). This study therefore concludes that the medicinal plant posses analgesic properties. Suppression of pain in this study could be attributed to phytochemical constituents present in the extract. Therefore, it is possible to obtain analgesic agent from the plant and serve as an alternative bio-resource in managing pain. However, further research on the mechanism action of the extract should be carried out. The study thus, scientifically confirms the traditional use of the medicinal plant in management of pain.

\section{Acknowledgements}

The authors are grateful to technical support provided by James Adino, Danie Gitonga and James Ngujiri.

\section{References}

1. Rajagopal R (2006) Pain - Basic Considerations. Indian Journal of Anaesthetic 5: 331-334.

2. Thorp CM (2008) Pharmacology for the Health Care Professions. A John Wiley \& Sons Ltd., London, UK, p: 243.

3. Craig CR, Stitzel RE (2003) Modern Pharmacology with Clinical Applications Lippincott Williams \& Wilkins, Philadelphia, 5th edn, p: 832.

4. Maze M, Hunter JC, Gaeta RR (2000) Conscious sedation and pain. In: Carruthers SG, Hoffman BB, Melmon KL, Nierenberg DW (eds.), Melmon and Morrelli's Clinical Pharmacology. 4th edn. McGraw-Hill, New York, USA.

5. Rang HP, Dale MM, Ritter JM, Flower MC (2006) Pharmacology. 7th edn, Churchill Livingstone, pp: 202-210.

6. Boursinos LA, Karachalios T, Poultisides L, Malizos M (2009) Do steroids conventional non-steroidal anti-inflammatory drugs and selective Cox-2 inhibitors adversely affect fracture healing. Journal of Musculoskelet Neuronal Interact 9: 44-52.

7. Sparkes A, Heiene R, Lascelles BD, Malik R, Sampietro LR, et al. (2010) NSAIDs and cats- it's been a long journey. Journal of Feline Medicine and Surgery 12: 519-538

8. Richard F, Michelle AC, Luigi XC (2008) Lippincott's Illustrated Reviews Pharmacology. Lippincott Williams \& Wilkins, Philadelphia, 4th edn, p: 564

9. Shah BS, Nayak BS, Seth AK, Jalalpure SS, Patel KN, et al. (2006) Search for medicinal plants as a source of anti-inflammatory and anti-arthritic agents. Pharmacognosy Magazine 2: 77-86.

10. Singh A, Malhotra S, Subban R (2008) Anti-inflammatory and analgesic agents from Indian medicinal plants. International Journal of Integrative Biology 1 : 57-72.

11. Komboj VP (2000) Herbal medicine. Current Science 78: 35-39.

12. Gupta M, Mazumder UK, Gomathi P, Selvan VT (2006) Anti-inflammatory activity of extract of Vernonia amygdalina. Complementary and Alternative Medicine 6: 36-43.

13. Matu EN (2008) Clutia abyssinica Jaub and Spach. In: Schmelzer GH, GuribFakim A (eds.), Medicinal plants/Plantes médicinales PROTA, Wageningen, Netherlands.

14. Lapah PT, Noa PA, Ogbonna OJ (2014) Anti-Pyretic and Analgesic Potentials of Aqueous Extract of Phragmanthera capitata S. Balle in Albino Rats. American Journal of Pharmacy and Pharmaceutical Sciences 1: 37-43.
15. Singh SD, Majumbar K (1995) Analysis of activity of Ocimum sanctum and its possible mechanism of action. International Journal of Pharmacology 3 : 188-192.

16. Akuodor GC, Anyalewechi NA, Udoh FV, Ikoro NC, Akpan JL, et al. (2011) Pharmacological evaluation of Verbena hastate leaf extract in the relief of pain and fever. Advances in Pharmacology and Toxicology 3: 1-8.

17. Ezeja MI, Ezeigbo II, Madubuike KG (2011) Analgesic activity of the methanolic seed extract of Buchholzia coriacea. Research Journal of Pharmaceutical Biological and Chemical Sciences 2: 182-187.

18. Trease GE, Evans MC (1983) Text book of Pharmacognosy. 12th edn. Balliere, Tindall: London, pp: 343-383.

19. Fujiyoshi T, Hayashi I, Ohishi S, Kuwashima M, lida H, et al. (1989) Kaolininduced writhing in mice, a new model of possible bradykinin-induced pain for assessment of analgesic agents. Agent and Actions 27: 332-334.

20. Collier HJ, Dinneen LC, Johnson CA, Schneider C (1968) The abdominal constriction response and its suppression by analgesics drugs in the mouse. British Journal of Pharmacology 32: 295-310.

21. Berkenkopf JW, Weichman BM (1988) Production of protacyclin in mice following intraperitoneal injection of acetic acid, phenylbenzoquinone and zymosan. Prostaglandins 36: 693-709.

22. Bentley G, Newton S, Starr J (1983) Studies on the antinociceptive action of $\alpha \square$ agonist drugs and their interactions with opioid mechanisms. British Journal of Pharmacology 79: 125-34

23. Inotai A, Hanko B, Meszaro A (2010) Trends in the non-steroidal antiinflammatory drug market in six central-eastern European countries based on retail information. Pharmacoepidemiology and Drug Safety 19: 183-190.

24. Davies P, Bailey PJ, Goldenberg MM, Ford-Hutchinson AW (1984) The role of arachidonic acid oxygenation products in pain and inflammation. Annual Review of Immunology 2: 35-54

25. Mworia JK, Gitahi SM, Juma KK, Njagi JM, Mwangi BM, et al. (2015) Antinociceptive Activities of Acetone Leaves Extracts of Carissa Spinarum in Mice. Medicinal and Aromatic Plants 10: 1- 4.

26. Kariuki HN, Kanui TI, Yenesew A, Patel NB, Mbugua MP (2012) Antinociceptive activity of Toddalia asiatica (L) Lam in models of central and pheripheral pain. Phytopharmacology 3: 122-129.

27. Gitahi SM, Maina MW, Njagi JM, Mworia JK, Juma KK, et al. (2015) Antipyretic Properties of Dichloromethane: Methanolic Leaf and Root Bark Extracts of Carissa edulis in Rats. Asian Journal of Biomedical and Pharmaceutical Sciences 5: 12-20.

28. Afsar T, Khan M, Razak S, Ullah S, Mirza B (2015) Antipyretic, anti-inflammatory and analgesic activity of Acacia hydaspica R. Parker and its phytochemical analysis. BMC Complementary and Alternative Medicine 15: 136-145.

29. Kumar A, Agarwal K, Maurya KA, Shanker K, Bushra U, et al. (2015) Pharmacological and phytochemical evaluation of Ocimum sanctum roo extracts for its anti-inflammatory, analgesic and antipyretic activities. Pharmacognosy Magazine 11: 17-24

30. Robak J, Gryglewski RJ (1996) Bioactivity of flavonoids. Polish Journal of Pharmacology 48: 555-564.

31. Tordera M Ferrandiz ML, Alcaraz MJ (1994) Influence of anti-inflammatory flavonoids on degranulation and arachidonic acid release in rat neutrophils. Journal of Biosciences 49: 235-240.

32. Uche FI, Aprioku JS (2008) The phytochemical constituents, analgesic and anti-inflammatory effects of methanol extract of Jatropha curcas leaves in mice and wister albino rats. Journal of Applied Sciences and Environmental Management 4: 990-102.

33. Kupeli E, Kosar M, Yesilada E, Baser K (2002) A comparative study on the antiinflammatory, antinociceptive and antipyretic effects of isoquinoline alkaloids from roots of Turkish Berberis species. Life Sciences 72: 645-657. 